\title{
Caffeine Catastrophe: Energy Drinks, Products Liability and Market Strategy
}

\author{
Evan A. Peterson ${ }^{1}$ \\ ${ }^{1}$ Department of Management, College of Business Administration, University of Detroit Mercy, Detroit, USA \\ Correspondence: Evan A. Peterson, College of Business Administration, Department of Management, University \\ of Detroit Mercy, 4001 W. McNichols Road, Detroit, MI 48221, USA. E-mail: petersea@udmercy.edu
}

\author{
Received: December 11, 2013 Accepted: January 13, 2013 Online Published: February 28, 2013 \\ doi:10.5539/ijms.v5n2p50 URL: http://dx.doi.org/10.5539/ijms.v5n2p50
}

\begin{abstract}
Despite widespread growth in the U.S. alternative beverage market in recent years, there are rising concerns that the producers of energy drinks, energy shots, and relaxation drinks have failed to adequately disclose potential health risks associated with consuming high levels of caffeine. In contrast to other caffeinated products, current FDA regulations do not require energy drinks to display comprehensive ingredient and warning labels. Consumer concerns have prompted a heightened discourse on the potential adverse health effects of energy drink consumption, a media call for investigation into the advertising practices of energy drink firms, a governmental push for greater regulation by the FDA, and a rise in products liability litigation. In order to reduce costs and better position themselves in the marketplace, U.S. energy drink firms must effectively manage the risks associated with producing and marketing these beverages in an increasingly hostile and inquisitive marketplace. Building on existing research, this article will examine three strategic options these firms can undertake in response to increasing products liability litigation and FDA regulation: product discontinuance, product relocation, and product offering modification. Based on major drawbacks associated with product discontinuance and product relocation, product offering modification offers the greatest potential to build consumer trust, decrease litigation costs, and respond to regulatory concerns.
\end{abstract}

Keywords: consumer protection, energy drinks, FDA regulation, market strategy, products liability

\section{Introduction}

Swift growth and impressive sales have made alternative beverages, such as energy drinks, energy shots, sports drinks, and vitamin-enhanced beverages, an increasingly vital component of the product offerings of major beverage companies in recent years. Despite economic crisis, the 2009 U.S. market for alternative beverages stood at nearly $\$ 17$ billion, and there are expectations that market growth will continue through 2014 (Gamble, 2010; Global Beverages Industry Profile, 2010; Landi, 2010). Despite this success, there are mounting concerns that these drinks promote reckless behavior and fail to adequately disclose the health risks associated with consuming high levels of caffeine (Iyadurai and Chung, 2007; Worrall, Phillips, and Henderson, 2005). Despite the potential health concerns, U.S. Food and Drug Administration (FDA) regulations associated with caffeinated products do not apply to the energy drink market. Consequently, the stringent labeling and health warning standards that are applied to other caffeinated products, such as over-the-counter caffeine pills and soft drinks, do not apply to energy drinks (Reissig, Strain, and Griffiths, 2009).

Deaths allegedly attributed to energy drinks have been reported in Australia, Ireland and Sweden (Kapner, 2004), fueling continued debate in the U.S. as to whether death can result from energy drink consumption (Reissig et al., 2009). In light of consumer concerns, advocates are clamoring for investigation into the advertising practices of energy drink firms and pushing for greater FDA regulation. In addition, scholars have also noted a rise in product liability lawsuits targeting energy drink consumption (Reissig et al., 2009; Dishneau and Perrone, 2012). Amidst the public concern, litigation, and legislative investigation surrounding products with perceived quality concerns, firms that best manage product liability and regulatory risks will have better opportunities to reduce costs and gain market share (Siedel and Haapio, 2010). The objective of this article is to examine how a strategic approach to combating products liability litigation through risk minimization can assist U.S. energy drink firms in obtaining a competitive advantage in the marketplace. Although existing literature has previously examined the relationship between products liability litigation and health concerns in the U.S. energy drink market, there has 
been little examination of the strategies that can be applied to combat and overcome prevailing consumer concerns. By examining this issue in greater detail, energy drink firms will be better able to reduce costs, develop superior products, and adapt to changing market conditions.

Building on current research, this paper will examine three strategic options U.S. energy drink firms can take in response to increasing products liability litigation and budding FDA regulation: product discontinuance, product relocation, and product offering modification. Based on major drawbacks associated with product discontinuance and product relocation, product offering modification offers the greatest potential to build consumer trust, decrease litigation costs, and respond to regulatory concerns. The following sections will outline how proactive modifications to energy drink product labeling will allow U.S. beverage firms to increase brand loyalty and alleviate the effects of products liability litigation and governmental regulation.

\section{Literature Review}

\subsection{U.S. Products Liability Laws}

Products liability law in the United States assigns liability to the manufacturers and sellers of products that cause harm to consumers. A form of strict liability, as preventive measures taken to avoid harm are irrelevant to the defense of a legal action, products liability law consists principally of three key doctrines: manufacturing defect, design defect, and failure to warn (Schotland, 2003). Under the manufacturing defect doctrine, liability for injury results if the particular unit of product that causes the harm is not manufactured consistently with the product's intended design (Restatement Second of Torts $\$ 395$; Restatement Third of Torts: Products Liability §2). The design defect doctrine renders companies liable for injury caused by a product if the very design of the product creates an unreasonable risk of injury and results in harm. In assessing a design defect, courts examine whether a reasonable alternative product design would have reduced the risks of harm created by the product, and whether the omission of this alternative design rendered the product unreasonably unsafe (Restatement Second of Torts \$398; Restatement Third of Torts: Products Liability §2). Finally, under the failure to warn doctrine, firms can be held liable if they fail to provide reasonable warning about the risks associated with use of their product. A product is defective under this doctrine when the risks of harm posed by its use can be avoided through reasonable warning labels. In other words, it is the omission of proper warning labels in these circumstances that renders the product unreasonably unsafe and triggers liability (Restatement Second of Torts $\S 388$. While this paper will focus on the failure to warn doctrine as it relates to the energy drink market, Owen (2005) provides a more detailed discussion on the three key doctrines of products liability law.

The goal of products liability law is to deliver incentives for firms to produce and market safer products (Biskupic, 2008), and as past lawsuits against tobacco companies, gun companies, and pharmaceutical companies have illustrated, the costs associated with product liability violations can reach billions of dollars (Henigan, 1999; Siedel and Haapio, 2010). However, certain scholars, industry professionals, and members of the business press have characterized product liability laws as haphazard, ineffective, and costly, arguing that such laws fail to deter defects, hinder innovation, and drive smaller companies out of business (Presser, 2002; Frank, 2007). As an alternative, these critics argue that market forces deliver appropriate incentives for companies to improve product safety, given that negative public information about product risks can instigate a sharp decline in consumer demand (Govindaraj, Jaggi and Lin, 2004; Andrews, 2006; Polinksy and Shavell, 2010). Nevertheless, sellers and manufacturers of goods with perceived quality concerns are cautioned to recognize how product liability law continues to drive mass tort litigation, and that a significant quantity of modern lawsuits allege injury and death at the hands of unsafe products (Hensler, 2007).

This constantly evolving area of law raises a variety of concerns for organizations that seek to achieve continued growth through the promotion of products with unknown or insufficiently tested safety ramifications. In the next section, I will provide a brief background on the energy drink market and introduce how concerns surrounding their potentially adverse health effects have given rise to increased examination, investigation, and litigation.

\subsection{Energy Drinks and the Beverage Market}

The widespread growth and consumption of high caffeine energy drinks has increased markedly in recent years. Global beverage giants like Coca-Cola and PepsiCo are increasingly relying on alternative beverages to sustain sales volumes in U.S. markets where increasing numbers of health-conscious consumers are reducing their consumption of carbonated soft drinks (Thompson, Peteraf, Gamble, and Strickland, 2012). In addition, alternative beverages are being progressively utilized to broaden product offerings in developing markets (Johnson, 2006). For the purposes of this paper, the term "energy drink" encompasses beverages that claim to enhance mental or physical energy, both in the traditional and new "shot" formats. Use of the term is not intended to include energy drinks that contain alcohol, naturally caffeinated beverages, or soft drinks. 
Despite ongoing economic crisis, political tension, and military conflict, the 2009 total worldwide beverage market exceeded $\$ 1,581$ billion, with beverage sales in the U.S.reaching nearly 29 billion gallons (Gamble, 2010; Global Beverages Industry Profile, 2010). The 2009 global market for alternative beverages topped $\$ 40$ billion, with $\$ 17$ billion in sales occurring in the U.S market alone. Experts approximate that global sales levels will reach $\$ 1,775.3$ billion by 2014 (Gamble, 2010; Global Beverages Industry Profile, 2010; Landi, 2010). In large measure, these impressive sales volumes are due to clever marketing campaigns. Energy drinks are often advertised in conjunction with claims outlining a variety of performance enhancing benefits, such as those evident in Red Bull's promotions that boast improved endurance, concentration, reaction speed, and metabolism (Red Bull website, 2012). However, challengers have questioned the validity of these claims for years (Reissig et al., 2009), and there is substantial debate over whether caffeine, a key ingredient in energy drinks, can legitimately have positive overall performance enhancing effects (Heatherley, Hayward, Seers, and Rogers, 2003; Haskell, Kennedy, Wesnes, and Scholey, 2005; Childs and de Wit, 2006). Moreover, energy drink producers have drawn considerable fire amidst allegations that their advertising campaigns idolize psychoactive behaviors to such a degree as to superficially glorify drug use (Miller, 2008; Reissig et al., 2009).

As a result of pursuing such marketing strategies, there are increasing concerns that energy drink ingredients, most notably caffeine, present a health risk for consumers (Koleva, 2010). For example, documented adverse consequences of caffeine use include nervousness, anxiety, restlessness, insomnia, stroke, seizure, tachycardia, psychomotor agitation, and even death in rare cases (American Psychiatric Association, 1994; Kerrigan and Lindsey, 2005; Worrall et al., 2005; Iyadurai and Chung, 2007). Deaths allegedly attributed to energy drink consumption have been reported inside the U.S. and abroad, in countries like Sweden, Australia, and Ireland (Kapner, 2004), sparking further debate surrounding the connection between energy drink consumption and death (Reissig et al., 2009). Consequently, products liability lawsuits are increasingly being filed in U.S. courts against companies that produce and sell energy drinks (Mundy, 2010; Meier, 2012). Moreover, the increased media attention surrounding this issue even led a Kentucky man accused of murder to briefly claim insanity due to sleep deprivation, deprivation that the Defendant claimed was brought on by excessive caffeine use (Weiss, 2010).

Multiple plaintiffs in products liability cases, as well as consumer groups and medical professionals, assert that the risks associated with energy drink ingestion are exponentially compounded by the lack of adequate warning labels and ingredient information. Although medical experts have been calling for warning labels on energy drinks for years (Johns Hopkins Medicine, 2008), current FDA regulations do not require energy drinks to disclose caffeine levels. Given that energy drinks can be marketed as dietary supplements, they are subject to specific regulatory categories with distinct labeling and ingredient requirements (Kapner, 2004; Reissig et al., 2009; Koleva, 2010; Goldberg 2012; Meier, 2012). While FDA officials assert there is not yet sufficient evidence that would allow them to take action on energy drink caffeine levels, consumers continue to push for greater regulation of these products on the open market (Meier, 2012). In addition, New York Attorney General Eric Schneiderman recently announced a state investigation into the safety and nutritional value of caffeine-intensive energy drinks. Moreover, senators Richard Durbin and Richard Blumenthal, respectively of Illinois and Connecticut, have demanded that the FDA institute extensive regulation of energy drink labels and ingredients (Dishneau and Perrone, 2012).

Given the increased scrutiny placed upon energy drinks in the wake of recent litigation, critical news publications, and demands for government investigation, the likelihood of heavy FDA regulation or outright ban in the near future is a rapidly increasing possibility. Such a decision by the FDA could prove disastrous for market share and firm profits. For example, the FDA decision in years past to ban certain alcoholic energy drinks from the US market, following a series of consumer deaths and hospitalizations (Fiore, 2010; Mundy, 2010), dealt a crippling blow to that segment of the alternative beverage market. Consequently, examination and modification of energy drink market business strategies is necessary for firms to adapt to an increasingly contentious business marketplace. The next section will examine several strategic approaches such organizations may utilize to proactively and preemptively address products liability litigation and potential FDA regulatory changes.

\section{Business Strategies and Solutions}

Today's global market operates within a complex legal environment where the lines separating lawful from unlawful conduct are distorted and vague (Stohl, Stohl, and Popova, 2009). However, out of the uncertainty comes the opportunity for organizations to use strategic legal thinking to achieve competitive advantage in the marketplace (Siedel, 2002; Bagley, 2008; Bird, 2008; DiMatteo, 2010). As noted by Siedel and Haapio (2010), firms that best minimize product liability risks will stand in better position to reduce costs, develop superior 
products, and adapt to changing environmental conditions. In order for organizations to achieve this objective, Siedel and Haapio (2010) further identified several approaches to products liability cost management: the strategic approach, the organizational approach, and the operations approach. Building on their research, the remainder of this article will focus on applying a strategic approach to combating products liability litigation and FDA regulation in the energy drink market, reserving examination of the organizational and operational approaches for future scholarship.

Organizational competitive strategy deals with management's tactics for effectively strengthening market position in fluctuating market conditions (Thompson et al., 2012). The strategic approach centers on the fundamental business question of whether, and in what capacity, a company should continue to create and sell products that subject it to liability (Siedel and Haapio, 2010). While organizations in this position are faced with numerous options, this article will focus on the three key alternatives: product discontinuance, product relocation, and product offering modification. As discussed in greater detail below, based on the significant drawbacks associated with product discontinuance and product relocation, energy drink beverage firms that undertake product offering modification have the greatest strategic potential to build consumer trust, decrease litigation costs, and respond to regulatory concerns.

\subsection{Product Discontinuance}

Given the potential rise in litigation expenses, compensatory damage awards, and public disapproval resulting from a product safety crisis, a logical starting point for strategic analysis involves an assessment of whether the manufacture of such products should continue (Putsis and Bayus, 2001). Although injuries caused by product defects can severely damage consumer confidence, notable recalls involving products from Coca-Cola and Mercedes Benz have demonstrated that consumer opinions on firm responsibility play a fundamental role in effective crisis management (Tucker and Melewar, 2005). Customers that believe suitable elimination processes were implemented are more likely to perceive a company as dependable and cooperative (Mishra, Heide, and Cort, 1998). Strategic, operational, and financial considerations render product elimination a rational option for organizations faced with rising costs across all industries (Argouslidis and Baltas, 2007). If an organization's current market opportunities contain attractive growth potential, maintaining existing product lineups is strategically advisable. A product line is suitable for divestiture if it has questionable long-term potential, is weakly positioned within the industry, or lacks strategic fit with overall company goals (Thompson et al., 2012).

While momentum is building behind consumer and legislative calls for action to address safety concerns associated with energy drink ingredients and labeling, considerable debated remains concerning the connection between caffeine consumption and adverse health effects (Haskell et al., 2005; Childs and de Wit, 2006; Reissig et al., 2009). As beverage producers habitually seek to increase profits through expanded product offerings (Thompson et al., 2012), and given the impressive sales figures energy drinks have yielded in recent years (Landi, 2010), indications of a decision to drop energy drink product offerings altogether are noticeably absent from contemporary media and public relations discussions. Hence, there is currently little catalyst for such a drastic strategic change. However, if existing litigation and investigative trends continue, the impending increase in litigation costs, FDA oversight and regulation will force beverage producers to reevaluate the decision of whether to carry energy drinks in their product lines.

\subsection{Product Relocation}

In light of drawbacks associated with product discontinuance, exasperated firms have traditionally opted to relocate product sales to new geographic markets. Historically, litigation and regulation have been far more onerous in the U.S. than other parts of the world. Organizations that wished to avoid the associated challenges marketed products with perceived safety concerns in countries lacking restrictive product liability laws (Schotland, 2003). However, as Siedel and Haapio (2010) note, the traditional tactic of relocating sales and operations to exploit legal deficiencies has become increasingly difficult with the global expansion of products liability laws. There is increasing recognition that products liability protection has become a global phenomenon (Reimann, 2003), as these laws are necessary for holding organizations accountable and assisting in the compensation of injured parties (Henderson and Twerski, 1999; Owen, 2005; Fairgrieve and Howells, 2007). For example, the European Union (EU) Product Liability Directive works as part of broader system of product safety laws, workplace safety laws, and consumer protection laws (Siedel and Haapio, 2010) that employs proactive regulation, rather than reactive litigation, to promote product safety (Howells, 2000). Additionally, EU laws also provide extensive remedies for injuries caused by defective products, even prohibiting the shipment of EU banned products to other countries (Reissig et al., 2009). 
The global migration of products liability law has profoundly affected the level of protections surrounding consumer safety, leading to the mixed governmental reception of energy drinks in varied international markets. Several EU states have enacted measures to regulate the labeling, distribution, and sale of energy drinks that contain significant quantities of caffeine, with some European countries, such as France, Sweden, and Denmark, electing to remove particular caffeinated energy drinks from the market altogether (Reissig et al., 2009; Goldberg 2012). EU requirements dictate that energy drinks containing an excess of $150 \mathrm{mg} / \mathrm{L}$ of caffeine must maintain warning labels that indicate the caffeine quantity alongside the phrase "high caffeine content" (European Union, 2002). Moreover, existing research indicates that these health conscious, caffeine cautious trends are reaching markets in the developing world, in tandem with the efforts of energy drink producers to secure greater global market share (Hoflander, 2011). Consequently, beverage producers that attempt to avoid U.S. products liability laws and burdensome FDA regulations by marketing energy drinks overseas face equally exacting regulatory challenges, and will be held accountable for injuries caused by their products under the globally expanding network of consumer safety laws (Siedel and Happio, 2010).

\subsection{Product Offering Modification}

Based on the above considerations, beverage firms that wish to continue selling energy drinks can no longer rely on market relocation to avoid liability. Proactive changes are necessary. The key to effective strategy is considering, understanding, and reacting to feedback provided by the market, as consumer complaints, warranty assertions, and even lawsuits provide key information about prevailing consumer opinions (Sidel and Happio, 2010). Existing scholarly literature, litigation statistics, news outlets, and social media discussions have illuminated the mistrust felt by the public towards a perceived lack of transparency surrounding the potential long term health effects of energy drink consumption. Based on such market feedback, energy drink firms must revamp product labels to adequately disclose caffeine levels, risks, warning signs, and consumption restrictions. This modification will proactively address key arguments raised in products liability litigation, as well as stimulate honest marketing practices that allow for better adaptation to changing market regulatory conditions.

Several noteworthy benefits support this approach. First, product information is readily available in the electronic age, irrespective of the level of information provided by energy drink firms themselves (Ausness, 2011). Information outlining product quality and product safety can be obtained from a variety of sources, including news media, consumer publications, social media websites, and independent blogs. Unsurprisingly, beverage producers have expressed apprehensions about placing new information in product labels and advertisements, fearing a potential decrease in sales. However, studies have shown that while product demand may slightly weaken in reaction to negative product information (Govindaraj et. al 2004; Andrews, 2006), the extent of the associated fallback depends on consumer perceptions of candor, transparency, and problem severity (Dean, 2004; Tucker and Melewar, 2005; Standop, 2006; Grunwald, 2008; Polinksy and Shavell, 2010). Therefore, companies that take greater strides to provide consumers with comprehensive product information will stand in a better position to build consumer trust, leading to increased market share and profits.

Second, the increased candor and transparency provided by including caffeine levels, usage risks, warning signs, and consumption restrictions in modified product labels will assist in building brand recognition and establishing consumer trust. Although new flavor combinations, product line extensions, and distribution capabilities are essential to increase beverage profits, branding provides crucial opportunities for producers to distinguish themselves in saturated markets (Thompson et al., 2012). In addition to proactively addressing potential future FDA regulations, new branding efforts will assist energy drink companies in appealing to consumers outside the customary young adult demographic. In fact, examples of this desired expansion are reflected in the recent decision by Living Essentials, the maker of 5 Hour Energy shots, to add pink lemonade to its flavor lineup. Advertisements accompanying this flavor introduction also reveal that a portion of sale proceeds will be donated to the Avon Foundation for Women Breast Cancer Crusade (5 Hour Energy website, 2012). Undertaking activities that enhance social legitimacy can support the development of competitive advantage through heightened brand recognition and reduced regulatory costs (Porter and Kramer 2006), as past research has demonstrated a positive long term relationship between corporate social performance and economic performance (Schnietz and Epstein, 2005; George and Sims, 2007; Wahba, 2008). Therefore, voluntary product label modifications can assist in building consumer trust, while concurrently reducing litigation and the public outcry for governmental investigation and supervision.

Third, revised labels will afford energy drink producers faced with products liability claims additional legal protections under the assumption of risk doctrine. Recognized as a defense to products liability claims, assumption of risk refers to circumstances where a product user voluntarily and unreasonably uses a product in disregard of known dangerous conditions surrounding that product (Amendola, Kennel, Levin, and Nagy, 2012). 
In making the legal determination whether assumption of risk should apply in a particular case, courts examine the product user's knowledge, understanding, and appreciation of the dangers connected to the product (Amendolaet al., 2012). However, certain jurisdictions do not recognize assumption of risk as a legitimate defense to products liability claims, absent extraordinary circumstances (Amendolaet al., 2012). Notwithstanding this selective recognition, in jurisdictions where the doctrine is recognized, modified warning labels containing additional information related to product ingredients, caffeine content, and usage risks will put consumers on notice of the potential adverse effects of product consumption. In turn, this notice will allow affected firms to utilize assumption of risk as a defense to products liability claims raised in litigation.

\section{Conclusion}

Swift growth and impressive sales have made energy drinks an increasingly vital component of the product offerings of major beverage companies in recent years. However, mounting concerns over the perceived adverse health effects associated with energy drink consumption have led to products liability litigation and calls for strict FDA regulation. Today's global market operates within a complex legal environment, and energy drink firms that best minimize product liability risks will stand in better position to reduce costs, develop superior products, and adapt to changing environmental conditions.

This article examined three strategic options for responding to increased products liability litigation and FDA regulation: product discontinuance, product relocation, and product offering modification. Based on major drawbacks associated with product discontinuance and product relocation, product offering modification offers the greatest potential to build consumer trust, decrease litigation costs, and respond to regulatory concerns. Specifically, research findings indicate that by revamping product labels to adequately disclose caffeine levels, risks, warning signs, and consumption restrictions, energy drink producers will proactively combat key arguments raised in products liability litigation and stimulate better adaptation to changing market regulatory conditions.

As with any scholarly inquiry, there are limitations that should be acknowledged. First, the scope of this study was confined to U.S. based energy drink firms and products liability laws. Given this restraint, it is appropriate to exercise caution when generalizing these results. Another limitation is that only three strategic options for responding to increasing products liability litigation and potential FDA regulation were examined: product discontinuance, product relocation, and product offering modification. The author recognizes that a variety of strategic options are available to U.S. energy drink producers wishing to combat products liability litigation through risk minimization, and that the conclusions reached in this article were drawn from these surveyed alternatives. In spite of these limitations, the conclusions that can be drawn from this article are still significant to researchers and organizations.

Scholars in a variety of disciplines have posed questions about the complex relationship between governmental regulation, products liability, and market strategy. Previous research provides some insight into potential strategic response measures to increased litigation and legal regulation. This paper builds on previous research by analyzing strategic options for adapting to the business environment wrought by consumer concerns regarding the safety of energy drink consumption. Conclusions in this paper may be used by scholars in management and law to further explore the relationship between law, products liability, and market strategy.

\section{References}

Amendola, F., Kennel, J., Levin, J., \& Nagy, C. (2012). Products Liability: Assumption of Risk. Corpus JurisSecundum, 72A(76).

American Psychiatric Association. (1994). Diagnostic and Statistical Manual of Mental Disorders: DSM-IV. Washington, DC: American Psychiatric Association.

Andrews, R. (2006). Managing the Environment, Managing Ourselves. New Haven, CT: Yale University Press.

Argouslidis, P., \& Baltas, G. (2007). Structure in Product Line Management: The Role of Formalization in Service Elimination Decisions. Journal of the Academy of Marketing Science, 35, 475-491. http://dx.doi.org/10.1007/s11747-006-0004-2

Ausness, R. (2011). Risky Business: Liability of Product Sellers who Offer Safety Devices as Optional Equipment. Hofstra Law Review, 39, 807-857.

Bagley, C. (2008). Winning Legally: The Value of Legal Astuteness. Academy of Management Review, 33, 378-390. http://dx.doi.org/10.5465/AMR.2008.31193254

Bird, R. (2008). Pathways of Legal Strategy. Stanford Journal of Law, Business and Finance, 14, 1-41. 
Biskupic, J. (2008). Court Draws Line on State Safeguards, USA Today, Feb. 21, 2008, at 3A.

Childs, E., \& de Wit, H. (2006). Subjective, Behavioral, and Physiological Effects of Acute Caffeine in Light, $\begin{array}{llll}\text { Nondependent } \quad \text { Caffeine } & \text { Users. }\end{array}$ http://dx.doi.org/10.1007/s00213-006-0341-3

Dean, D. (2004). Consumer Reaction to Negative Publicity: Effects of Corporate Reputation, Response, and Responsibility for a Crisis Event. Journal of Business Communication, 41(2), 192-211. http://dx.doi.org/10.1177/0021943603261748

DiMatteo, L. (2010). Strategic Contracting: Contract Law as a Source of Competitive Advantage. American Business Law Journal, 47(4), 727-794. http://dx.doi.org/10.1111/j.1744-1714.2010.01108.x

Dishneau, D., \& Perrone, M. (2012). FDA: 5 Reported Deaths with Monster Drink Link. Retrieved November 1, 2012 from http://finance.yahoo.com/news/fda-5-reported-deaths-monster-drink-194623537--finance.html

European Union. (2002). Commission Directive 2002/67/EC of 18 July 2002 on the Labeling of Foodstuffs Containing Quinine, and of Foodstuffs Containing Caffeine. Retrieved November 21, 2012 from http://eurlex.europa.eu/LexUriServ/site/en/oj/2002/1_191/1_19120020719en00200021.pdf

Fairgrieve, D., \& Howells, G. (2007). Rethinking Product Liability: A Missing Element in the European Commission's Third Review of the European Product Liability Directive. The Modern Law Review, 70(6), 962-978. http://dx.doi.org/10.1111/j.1468-2230.2007.00672.x

Fiore, K. (2010). FDA Will Ban Alcoholic Energy Drinks, Sen. Says. Retrieved November 1, 2012 from http://abcnews.go.com/Health/Wellness/fda-ban-alcoholic-energy-drinks-sen/story?id=12164536

Five Hour Energy. (2012). 5-Hour Energy Introduces Pink Lemonade FlavorSales to support Avon Foundation for Women Breast Cancer Crusade. Retrieved November 11, 2012 from http://www.5hourenergy.com/5hrNews-2012-09-24.asp

Frank, T. (2007). Rollover Economics: Arbitrary and Capricious Product Liability Regimes. Retrieved November 1, 2012 from http://www.aei.org/files/2007/01/04/20070104_LiabilityOutlookPosted_g.pdf

Gamble, J. (2010). Competition in Energy Drinks, Sports Drinks, and Vitamin-Enhanced Beverages. Mobile, AL: University of South Alabama.

George, B., \& Sims, P. (2007). True North. Discover Your Authentic Leadership. San Francisco, CA: Wiley \& Sons.

Global Beverages Industry Profile. (2010). Datamonitor.

Goldberg, K. (2012). Consumer Warning - Caffeinated Energy Drinks Can Kill You! Retrieved November 1, 2012 from http://www.marylandinjurylawyersblog.com/2012/01/consumer-warning---caffeinated.html

Govindaraj, S., Jaggi, B., \& Lin, B. (2004). Market Overreaction to Product Recall Revisited — The Case of Firestone Tires and the Ford Explorer. Review of Quantitative Finance and Accounting, 23(1), 31-54. http://dx.doi.org/10.1023/B:REQU.0000037063.91860.87

Haskell, C., Kennedy, D., Wesnes, K., \& Scholey, A. (2005). Cognitive and Mood Improvements of Caffeine in Habitual Consumers and Habitual Non-consumers of Caffeine. Psychopharmacology, 179(4), 813-825. http://dx.doi.org/10.1007/s00213-004-2104-3

Heatherley, S., Hayward, R., Seers, H., \& Rogers, P. (2005). Cognitive and Psychomotor Performance, Mood, and PressorEffects of Caffeine after 4, 6 and 8 h Caffeine Abstinence. Psychopharmacology, 178(4), 461-470. http://dx.doi.org/10.1007/s00213-005-2159-9

Henderson, J., \& Twerski, A. (1999). What Europe, Japan, and other Countries Can Learn from the New American Restatement of Products Liability. Texas International Law Journal, 34, 1-20.

Henigan, D. (1999). Sue The Gun Makers. Washington Post, Oct. 29, 1999, at A31.

Hensler, D. (2007). Has the Fat Lady Sung? The Future of Mass Toxic Torts. Litigation Review, 26, 883-85.

Hoflander, J. (2011). A Red Bull Instead of a Cigarette: Should the FDA Regulate Energy Drinks? Valparaiso University Law Review, 45, 689-740.

Howells, G. (2000). The Relationship between Product Liability and Product Safety-Understanding a Necessary Element in European Product Liability through a Comparison with US position. Washburn Law Journal, 39, 305-346. 
Iyadurai, S., \& Chung, S. (2007). New-onset Seizures in Adults: Possible Association with Consumption of Popular Energy Drinks. Epilepsy Behavior, 10, 504-508. http://dx. doi.org/10.1016/j.yebeh.2007.01.009

Johns Hopkins Medicine. (2008). Caffeine Experts at Johns Hopkins Call for Warning Labels for Energy Drinks, 2008. Retrieved November 3, 2012 from http://www.hopkinsmedicine.org/news/media/releases/Caffeine_ Experts_at_Johns_Hopkins_Call_for_Warning_Labels_for_Energy_Drinks

Johnson, C. (2006). Caffeine-Stoked Energy Drinks worry docs. Retrieved November 1, 2012 from http://www.washingtonpost.com/wp-dyn/content/article/2006/10/29/AR2006102900290.html

Kapner, D. (2004). Ephedra and energy drinks on college campuses. Retrieved November 1, 2012 from http://www.higheredcenter.org/files/product/energy-drinks.pdf

Koleva, G. (2010). Energy Drinks faulted for not Disclosing Excessive Caffeine. Retrieved November 1, 2012 from http://www.dailyfinance.com/2010/10/29/energy-drinks-faulted-for-not-disclosing-excessive-caffeine

Landi, H. (2010). A Market in Decline. Beverage World, 129(4), S2. http://dx.doi.org/10.3200/JACH.56.5.481-490

Meier, B. (2012). F.D.A. Receives Death Reports Citing Popular Energy Drinks. Retrieved November 3, 2012 from http://finance.yahoo.com/news/f-d-receives-death-reports-185008634.html

Miller, K. (2008). Wired: Energy Drinks, Jock Identity, Masculine Norms and Risk Taking. Journal of American College Health, 56, 481-489.

Mishra, D., Heide, J., \& Cort, S. (1998). Information Asymmetry and Levels of AgencyRelationships. Journal of Marketing Research, 35, 277-295. http://dx.doi.org/ 10.2307/3152028

Mundy, J. (2010). Energy Drink Lawsuits from Wrongful Death to Wrongful Advertising: Next Up FRS? $\begin{array}{llll}\text { Retrieved November } & 3, & 2012 & \text { from }\end{array}$ http://www.lawyersandsettlements.com/articles/frs-healthy-energy/interview-frs-energy-healthy-3-15517.ht $\mathrm{ml}$

Owen, D. (2005). Products Liability Law. New York, NY: West Publishing.

Polinksy, A. M., \& Shavell, S. (2010). The Uneasy Case for Product Liability. Harvard Law Review, 123, 1438-1492.

Porter, M. E., \& Kramer, M. R. (2006). Strategy and Society: The Link between Competitive Advantage and Corporate Social Responsibility. Harvard Business Review, 2-15.

Presser, S. (2002). How should the Law of Products Liability be Harmonized? What Americans can learn from Europeans. Retrieved November 3, 2012 from http://www.manhattan-institute.org/html/gli_2.htm

Putsis, W. P. Jr., \& Bayus, B. L. (2001). An Empirical Analysis of Firms' Product Line Decisions. Journal of Marketing Research, 38, 110-118. http://dx.doi.org/10.1509/jmkr.38.1.110.18830

Red Bull website. (2012). Retrieved November 3, 2012 from http://www.redbullusa.com/cs/Satellite/en_US/Red-Bull-Energy-Drink/001242989766321

Reimann, M. (2003). Liability for Defective Products at the Beginning of the Twenty-First Century: Emergence of a Worldwide Standard? American Journal of Comparative Law, 51, 756-60. http://dx.doi.org/10.2307/ 3649130

Reissig, C., Strain, E., \& Griffiths, R. (2009). Caffeinated Energy Drinks: A Growing Problem. Drug and Alcohol Dependence, 99, 1-10. http://dx.doi.org/10.1016/j.drugalcdep.2008. 08.001

Restatement Second of Torts $\$ 388$ (1965).

Restatement Second of Torts $\$ 395$ (1965).

Restatement Second of Torts $\$ 398$ (1965).

Restatement Third of Torts: Products Liability §2. (1998).

Rogers, P., Martin, J., Smith, C., Heatherley, S., \& Smit, H. (2003). Absence of Reinforcing Mood and Psychomotor Performance Effects of Caffeine in Habitual Non-consumers of Caffeine. Psychopharmacology, $167,54-62$.

Schnietz, K., \& Epstein, M. (2005). Exploring the Financial Value of a Reputation for Corporate Social Responsibility during a Crisis. Corporate Reputation Review, 7(4), 327-345. http://dx.doi.org/10.1057/palgrave.crr.1540230 
Schotland, S. (2003). Overview of U.S. Product Liability Regime. Arizona Journal of International and Comparative Law, 20(1), 135-141.

Siedel, G. J. (2002). Using the Law for Competitive Advantage. San Francisco, CA: Jossey-Bass.

Siedel, G. J., \& Haapio, H. (2010). Using Proactive Law for Competitive Advantage. American Business Law Journal, 47, 641-686. http://dx.doi.org/10.1111/j.1744-1714.2010.01106.x

Stohl, C., Stohl, M., \& Popova, L. (2009). A New Generation of Corporate Codes of Ethics. Journal of Business Ethics, 90(4), 607-622. http://dx.doi.org/10.1007/s10551-009-0064-6.

Thompson, A., Peteraf, M., Gamble, J., \& Strickland, A. J. (2012). Crafting \& Executing Strategy: The Quest for Competitive Advantage (18th ed.). New York, NY: McGraw-Hill Irwin.

Tucker, L., \& Melewar, T. (2005). Corporate Reputation and Crisis Management: The Threat and Manageability $\begin{array}{lllll}\text { of Anti-corporatism. } & \text { Corporate Reputation }\end{array}$ http://dx.doi.org/10.1057/palgrave.crr.1540233

Wahba, H. (2008). Does the Market Value Corporate Environmental Responsibility? An Empirical Examination. Corporate Social Responsibility and Environmental Management, 15, 89-99. http://dx.doi.org/10.1002/csr.153

Weiss, D. (2010). Murder Defendant Claims Caffeine Insanity. Retrieved November 1, 2012 from http://www.abajournal.com/news/article/murder_defendant_claims_caffeine_insanity

Worrall, B., Phillips, C., \& Henderson, K. (2005). Herbal Energy Drinks, Phenylpropanoid Compounds, and Cerebral Vasculopathy. Neurology, 65, 1137-1138. http://dx.doi.org/10.1212/01.wn1.0000178985.35765.e0 